\title{
From Domination to Emancipation and Freedom: reading Ernesto Laclau's post-Marxism in conjunction with Philip Pettit's neo-republicanism
}

\author{
Gulshan Khan
}

\section{Introduction}

Since the publication of Hegemony and Social Strategy in 1985, Ernesto Laclau and Chantal Mouffe are widely acknowledged as leading representatives of post-Marxism and 'radical democratic' theory. They have sought to transform the left political imaginary beyond the impasses characteristic of traditional Marxist categories (Sim, 2000: Wenman, 2003). Both Laclau and Mouffe in their single authored works have developed distinct and original contributions to political theory. Mouffe, has engaged with mainstream political theory and developed her own agonistic approach (Mouffe, 1993, 2000, 2005; Wenman, 2003). Laclau has reworked of a range of concepts drawn not only from Marxism, but also in part from other traditions across political theory and political science. This is evident not just in Hegemony and Social Strategy, but also in his subsequent publications: New Reflection on the Revolutions of Our Times (1990), Emancipation(s) (1996), and On Populist Reason (2005). In these texts, Laclau creatively rereads key concepts - such as hegemony, populism, emancipation, and representation - through the lenses of poststructuralism, and to further develop and re-signify these ideas in innovative directions. He sought specially to augment the legacy of the Italian Marxist Antonio Gramsci, and to further develop the Gramscian emphasis on politics, or the realm of the 'superstructures', i.e. against reductionist or 'economistic' readings of Marxism. For Laclau, this was an effort to explain the growing diversity of struggles - not only socialist struggles, but also feminism, environmentalism, etc. - from the late 1960s onwards. In so doing, he fashioned a range of innovate concepts - for example the idea of a struggle over 'empty signifiers' and the need for a 'chain of equivalence' between alternate demands - each designed to explain the dynamics at play in the struggle for emancipation and freedom. Of course, these accomplishments have not been without controversy. They have, for example, provoked a hostile reaction from those committed to traditional Marxist forms of analysis (See Geras, 1988; Terry Eagleton: 1991). Despite these responses however, Laclau is arguably the foremost post-Marxist of the late twentieth century and the influence and impact of his work is gradually growing. Four years after his untimely death, Laclau's legacy is flourishing. This is evident, in the growing influence of the Essex School of discourse analysis which was founded by Laclau and where his ideas have been further developed by subsequent generations of thinkers; most notably by David Howarth and Jason Glynos who have developed the methodological approach of 'social logics' of critical explanation (social, political and fantasmatic), which explicitly reworks Laclau's and Mouffe's post-Marxism (Howarth, 2000, 2010; Glynos and Howarth, 2007). More generally, Laclau's categories continue to influence new generations of radical left thinkers; from key political figures in Latin America to those associated with Syrizia in Greece and PODEMOS in Spain. Moreover, his ideas are gradually gaining more traction within mainstream political science, which remains the most sophisticated account of this pressing contemporary phenomena.

In the secondary literature, Laclau's work has most often been contrasted with other continental thinkers, for example with the contributions of Gilles Deleuze, Antoni Negri, William Connolly, Slavoj Žižek, Jacques Rancière and Alain Badiou. These are valuable and interesting contributions, which have, for the most part, focused on the ontological differences between these various thinkers, seen for example variously as theorists of 'abundance' and 'lack'. Here, I take a new and different approach, one that amalgamates the respective strengths of continental and analytical theory to provide a multi-layered analysis of contemporary forms of domination and to better aid our understanding about the kinds of struggle needed to address them. My objective is to keep the focus on Laclau's contribution to political theory, and to evaluate the political implications of Laclau's post-Marxist understanding of the concepts of domination and conversely of emancipation and freedom. To scrutinise these ideas, I bring Laclau's approach into conversation with another important contemporary political theorist with whom Laclau would not normally be associated. This is Philip Pettit, who works broadly within the analytical tradition of 
contemporary political theory, and who in several important works - and most notably Republicanism: $a$ theory of freedom and government in 1999 - has developed an influential neo-republican conception of liberty as 'non-domination'. Pettit's impact on Anglo-American theory is significant to the point that neorepublicanism is the 'major alternative to liberal political theory' (Besson and Marti, 2009: 3). The paper weaves back and forth exploring points of similarity and difference between Laclau and Pettit, and this juxtaposition brings out aspects of Laclau's theory that are perhaps otherwise overlooked. My objective is not simply to dismiss Pettit's approach, and in fact we see that there is much to be admired in the neo-republican conception of non-domination, but an examination of the limits of Pettit's perspective also helps to foreground the strengths of Laclau's theory and vice versa. This reading discloses the important elements that are carried over from the classical Marxist categories, and creatively readapted in Laclau's post-Marxism. This comparison takes us beyond an interpretative exercise to better address complex forms of power and domination in late modern society.

On one level, we see that Pettit and Laclau share much in common. Like Laclau, Pettit's approach focuses on prospects for changing existing institutions so they better serve the freedom of citizens. Pettit avoids the worst excesses of the tendency towards abstraction which often defines analytical, or 'ideal theory'. At the core of Pettit's theory is his notion of liberty as non-domination, which he draws from the republican tradition, but of course this language of domination/non-domination is also associated with Marxism, as well as other critical approaches such as feminism. Indeed, as we will see: the concepts of domination, emancipation and freedom each have shared roots in both the republican and Marxist traditions, and part of my objective here is to compare their respective reworkings of this common heritage. ${ }^{1}$ Indeed, both Laclau and Pettit aim to reconfigure power and domination towards more democratic and egalitarian relations. In Laclau's terminology we could say that - in different ways - they each seek to expand the logic of equality within the public realm. Furthermore, because of these broad shared objectives, Laclau and Pettit also share a common aversion towards liberal conceptions of freedom in terms of non-interference or 'negative liberty'. From each of their respective viewpoints, liberal conceptions of freedom are inadequate because they do not take account of what Pettit, following in the republican tradition, calls 'arbitrary power', which can still operate in society even when there may be no explicit interference in the 'free' choices of individuals.

Despite these common points of reference, we see also that the two authors exhibit considerable differences, and that these variations have significant consequences for their respective conceptions of politics. These dissimilarities manifest across two key and interrelated fault lines. The first is in their respective conceptions of agency. Here, we see that Pettit, like many in the analytical tradition, works with methodological individualism, whereas Laclau develops a complex account of structure and agency, that is, in his account of what he calls structural 'dislocation'. Indeed, for Pettit, individuals are the always the potential bearers of either arbitrary power or freedom and when he attempts to explain more structural manifestations of power, ${ }^{2}$ he effectively models collective or group agency on methodological individualism. By way of contrast, Laclau starts from the (Althusserian) premise that the dominant structures 'interpellate' individuals as subjects, but, on Laclau's account, they fail repeatedly to achieve this aim, that is with any completion or 'totality'. Moreover, it is in this constitutive failure of social structures to ever fully determine an objective order, that we find the potential emergence of a subject of freedom and emancipation, i.e. in a moment of structural 'dislocation' (Laclau, 1996: 101; 1996b: 54). ${ }^{3}$ These are crucial differences, and they lead, in turn, to another key distinction between the two authors, which is that for Pettit political freedom is a mode of contestability within the established institutions, whilst Laclau's notions of emancipation and freedom functions at the level of competing hegemonic projects, and this facilitates a form of political struggle that might transcend the existing regime to instantiate a new institutional order.

\footnotetext{
${ }^{1}$ It is important to note that there is an alternative mode of the neo-republican revival within contemporary continental theory. See: Hardt and Negri, 2009.

2 See for example, McCormick, 2003; Markell, 2008; Hirschmann, 2009; Thompson, 2013.

${ }^{3}$ For Laclau, dislocation is inscribed into the logic of any structure and it is the trace of contingency within the structure.
} 
The paper is divided into three sections. In the opening section, I compare Laclau's and Pettit's respective conceptions of 'domination'. We see that Pettit's neo-republican theory provides valuable resources for understanding the exercise of arbitrary power by an individual, which he models on the relationship between master and slave. However, despite his acknowledgment that the cultural, economic and legal organisation of society enables some people to invade the choices of others, Pettit's emphasis on the limiting the capacity of one agent to exercise power over another cannot adequately account for structural domination such as unequal social relations, and this is in marked contrast to Laclau. Moreover, Laclau introduced a set of conceptual distinctions between domination, subordination, and oppression and these categories add further depth to the analysis of arbitrary power of an individual's will and influence. They draw attention to the crucial moment when subordinate groups become conscious of their 'oppression' and a social space emerges to draw the existing institutions into question and provide an alternative. The differences between the neo-republican and Laclau's post-Marxist theory are highlighted in this section regarding two alternate readings of Henrik Ibsen's play A Doll's House.

In the second section, I examine their respective understandings of 'emancipation' and 'freedom'. Again, we see that the idea of emancipation, and the associated idea of 'liberation', is derived both from the republican and Marxist traditions. However, Pettit does not model his theory of freedom as nondomination on the idea of emancipation, and this is despite his reference to the master and slave relationship. This stands in contrast to Laclau, for whom emancipation remains the focal point of political struggle, despite formal equality, and who maintains the idea of the possibility of a more radical transformation in the underlying structures of society. In fact, Laclau retains key elements of the Marxist conception of emancipation, and the differences between Pettit and Laclau are further illustrated here regarding Marx's famous distinction between 'political' and 'human emancipation'. In addition, Laclau differentiates between emancipation and freedom, and he understands 'freedom' in terms of indeterminacy as well as self-determination.

In the final section, I consider more generally Laclau's and Pettit's alternative conceptions of politics. We see that both thinkers place a premium on democratic contest in challenging and overturning arbitrary power. Nevertheless, in keeping with the differences which have emerged in the earlier sections, we see also that Pettit understands contestability as a politics of 'redress' within the existing institutions, whereas Laclau's focus is on the struggle for hegemony and the possibility of transformation in the present institutional order. I conclude with the suggestion that the neo-republican and post-Marxist conceptions of politics each outline important elements in the struggle against subordination and domination.

\section{Neo-republicanism and Post-Marxism: on domination, subordination and oppression}

At the core of Pettit's neo-republican theory is the idea that political agents are free when they are not subject to arbitrary controlling power by an alien individual will. This is distinct from the characteristically liberal view, as defended for example by Isiah Berlin, which associates freedom with the absence of interference or obstacles (Berlin, 1969). For Pettit, an individual can be subject to the impact of domination or arbitrary power where the capacity for such interference exists, even when there are no explicit obstacles to his/her free choice, or when the power to interfere in those choices is not directly exercised. Domination is the 'alienating control on the part of other persons', and to experience nondomination is therefore not only to find yourself unconstrained by others, but more importantly, to find yourself in a situation where no one has the potential to interfere on an arbitrary basis in the choices that you make (Pettit, 1997: 52, 67; 2012: 84). ${ }^{4}$ Along with other contemporary neo-republican theorists such as Quentin Skinner, Pettit invokes the relationship between the master and the slave to illustrate what is at issue in a relationship of 'domination'. Under ancient conditions of slavery, the slave is dependent on the master and at his mercy. This is particularly evident in the circumstances of the 'lucky' slave who happens to have a benevolent master. Although this slave may live a contented life, the slave's relative security

\footnotetext{
${ }^{4}$ See Pettit 1997 for his earlier notion of arbitrary power as not tracking the avowable interests of those affected by it (30).
} 
remains entirely dependent on the good will of his master. The master has arbitrary control or dominium over the slave and this state of dependency creates uncertainty and unpredictability for the slave, in response to which the slave develops a servile and slave like mentality. In ancient Roman society, a comparable dynamic was also inherent in the relationship between the head of the household, the pater familas, and his wife and children. This is evident in the etymology of the English term domination, which has its roots in Roman law and is derived from the Latin word dominatus referring to a ruler or master (dominus) of a house (domus) (Lovett, 2010: 3). Unlike the slave who was considered a 'thing' and literally the property of the master, Roman women and children had the status of legal persons in Roman law, but they were nonetheless still dependent on father/husband who had responsibility for them, who could exercise autocratic power over them and who were ultimately at the mercy of his goodwill. This conception of 'dependency' is at the core of the ancient idea of domination, and Pettit reworks this idea in his theory of 'arbitrary power'. Conversely, Pettit describes freedom as not 'having to depend on the grace or mercy of others, being able to do one's thing without asking their leave or permission' (Pettit, 2003: 394).

Pettit uses Henry Ibsen's A Doll's House to further demonstrate the difference between the liberal notion of freedom as non-interference and his notion of freedom as non-domination (Pettit, 2014: xiii). I recount his reading of this play because this also helps to differentiate Pettit's interpretation of domination from Laclau's. A Doll's House is set in nineteenth century Norwegian society and narrates the domestic affairs of the Helmer household. Nora Helmer, the wife of a successful banker Torvald (who is on the verge of a promotion), is being blackmailed by Krogstad (a bank employee) about a loan she took out early in her marriage to help pay for Torvald's treatment when he was ill. Such a revelation will destroy Torvald's honour and therefore his career. Torvald is sickened when he discovers that Nora lied and acted like a 'criminal' by forging her father's signature on the official loan papers (Ibsen, 2014: 59). However, once the creditor Krogstad sends back the bond of her debt, Torvald forgives Nora. He reconciles himself to her deed, with the thought that her fraudulent actions were a manifestation of her infantile behaviour. ${ }^{5}$ Pettit says that Nora 'is the doll in the doll's house, not a free woman' (Pettit, 2014: xiv). Indeed, for Pettit, Nora's relationship with Torvald is exemplary of the relationship of domination. Although Torvald does not directly interfere with Nora, she nonetheless remains unfree (i.e. despite her 'negative liberty') because she censors her actions to stay within Torvald's approval. In other words, she adopts a servile mode of behaviour. For example, she covertly eats macaroons because Torvald frowns upon her eating them. Pettit says that Nora's freedom is dependent upon Torvald's good grace, and if Torvald withdrew his goodwill she would be subject to his arbitrary power (Pettit, 2014: xv). On Pettit's account, for Nora to be truly free she needs to be free from domination, and, as he sees it, this requires safeguards against arbitrary interference in one's choices as well as resources and legal protections against anyone else's capacity to interfere (Pettit, 2014: xv).

These are important insights into the machinations of power, and this neo-republican view has had a significant impact across contemporary political theory. However, Pettit has elaborated his conception of domination within a methodologically individualist approach where it is individual 'agents' who are the bearers of arbitrary power, or conversely who can be agents of freedom. If structural forms of power were to count as 'domination' then, according to Pettit, we 'would lose the distinction between securing people against the natural effects of chance and incapacity and securing them against the thing that they may try to do to one another' (Pettit, 1997: 52-3). However, this set of alternatives is too limited. In addition to the consequences of interfering actions by one agent over another and the natural effects of chance, from a post-Marxist perspective we need to grasp also the impact of other modes and asymmetries of power such as rank, status, influence and control, i.e. those that take systemic forms of subordination, such as the unequal distribution of wealth in society, or the processes of normalisation that leave some individuals and groups in positions of privileged and superior status and others in a subordinate or inferior position. These

\footnotetext{
${ }^{5}$ Nora is a relation of servitude to Krogstad until the bond of her debt is returned. Indeed, Torvald acknowledges that 'there can be no freedom or beauty about a home life that depends upon borrowing or debt' (Ibsen, 2014: 5).
} 
modes of 'domination' cannot be reduced to natural inequalities or chance, but nor can they be readily traced to the capacity of one agent to exercise his/her will over another. Pettit's approach contrasts with many feminists, for whom 'male domination is a structural and institutionalised feature of a whole society' embedded in norms and practises (Friedman, 2008: 256). However, it also contrasts with more 'critical' republicans who similarly appreciate that patriarchy permeates throughout society in dominant social norms that hinder women even when they are formally legal citizens (Laborde: 2008: 16, 48). ${ }^{6}$ Indeed, it is crucial to appreciate that the systemic causes of patriarchy and other forms of domination cannot be readily referred to will or to the capacity for one agent to interfere in the choices of another agent, and here Laclau's theory can be particularly instructive.

Laclau's poststructuralist conception of structure and agency retains core elements of the conventional Marxist understanding of the role of structures in shaping social subjectivities. At the heart of Laclau's approach, is a reworking of the Marxist idea that we are 'bearers of historical structures', or, as Laclau puts it, of the dominant 'discourses' that, following Louis Althusser, socialise (interpellate) us as subjects (Laclau, 1990). However, Laclau rejects the idea that capitalist relations of exploitation always have an overriding priority (even in the 'last instance'), and, as I have already said in the introduction, he additionally stresses the constitutive incompletion of structural closure or 'totality'. These processes of structural determination are never fully determinate or complete, and it is this inherent 'dislocation' of structural closure that leaves open a certain space for agency or freedom, 'insofar as [agents] actualise certain structural potentialities and reject others' (Laclau, 1990: 30). Moreover, this model of incomplete or dislocated structure is further accentuated with reference to a poststructuralist account of identity formation. Again, in contrast to Pettit's conception of the relationships formed between individual agents, on Laclau's account: identities are not initially self-referential, but rather always already (i.e. essentially) formed in relation to one-another (Laclau, 1990). In addition, these dynamics of intrinsic relationality are inherently relationships of power, i.e. where certain options are available, whilst others are necessarily suppressed or foreclosed (Laclau, 1990: 18). In other words, relations of identity involve hierarchy and exclusions which demarcate and distinguish one identity from another. ${ }^{7}$

These are crucial methodological discernments, and because of these insights Laclau further proceeds to differentiate between alternative forms of identity/relations. Most importantly, for the discussion here, in his co-authored work with Chantal Mouffe, Laclau struck a crucial distinction between the concepts of subordination, oppression, and domination. In Laclau's approach each of these terms carries specific connotations, and it is evident that the term 'domination' here has a somewhat different meaning to the neo-republican conception of arbitrary power that I have just outlined above. In fact,

\footnotetext{
${ }^{6}$ Pettit has more recently sought to address structural forms of domination where he acknowledges that certain economic, cultural and legal conditions, enables some people to interfere with the choices of others (Pettit, 2012: 62). His response has been to limit the capacity for agents to exercise interference in other people's choices and he sees law as the best means to address this. This move is to be welcome; however, this nonetheless reflects Pettit's methodological individualism. Changes in the law and forms of law enforcement are very important measures and protections, but they are not equivalent to a change in the wider conditions such as norms, practices and processes that sustain entrenched relations of subordination and hierarchy that are reproduced through seemingly innocuous everyday practices and forms of socialisation embedded in institutions. See Kolodny, 2014b for why the law is not sufficient for social equality.

7 In some of his earliest writings, Pettit also engaged the traditions of French (post)structuralism or anti-phenomenologists (Pettit, 1975). However, two key differences distinguish Pettit's and Laclau's reading of Saussure's structural model of signification. Firstly, Pettit appears to accept Saussure's synchronic approach to language as a closed system of differences. This has the effect of naturalising the existing structure, whereas Laclau's poststructuralism rejects the fixity and closure of any system, draws attention to the power relations that sustain semantic units and rules, and emphasises the subject's capacity to challenge the predominant discourse. Secondly, Pettit claims that Saussure's structural model of meaning, with its account of structure in terms of the relations between the units within a language, cannot be carried over from the linguistic to nonlinguistic domains (Pettit, 1975: 70). For Pettit, Althusser, Lacan and Foucault cannot be counted as structuralists under the definition he uses. This is because there is nothing in Althusser's 'ideology', Foucault's 'archive', and Lacan's 'unconscious' to 'correspond properly to the [structural role of the] sentence in a language' and are instead languages [structures] in their own right (Pettit, 1975: 70). This is an important difference between Pettit and Laclau, and provides some explanation regarding how the word 'structure' is used in their respective approaches. For Pettit, structure is theorised in an individualist manner.
} 
Laclau uses the term subordination (and not domination) to describe an asymmetrical relationship of arbitrary power, where one 'agent is subjected to the decisions of another' (Laclau and Mouffe, 1985: 153). ${ }^{8}$ This unequal and asymmetrical relation between two or more agents is not a one-off instance nor is it a relation of oppression (as we shall see below), but entrenched or sedimented norms and practices in society. Such situations are still widespread in families (husband/wife) and workplaces (employer/employee) and are not necessarily doubted by those engaged in them (Laclau and Mouffe, 1985: 153). ${ }^{9}$ However, what interests Laclau are the circumstances by which these hierarchical relations come to be seen as illegitimate, i.e. seen as relationships of 'oppression', from the perspective of subordinate groups and/or individuals. Pettit's focus is on the individual agent and this is also the case for others who use the term domination in the analytical tradition. ${ }^{10}$ Laclau defines the circumstances of 'domination' precisely in terms of a moment of awaking, i.e. when the subordinate agent begins to perceive a set of hierarchical relations as unfair or unjust (Laclau and Mouffe, 1985: 159). This is further linked to another core category in Laclau's approach which is the notion of 'antagonism'. As we will see in more detail in the subsequent sections, Laclau envisages political struggle in terms of the circumstances by which subjugated identities come to realise that some external identity or practice, i.e. the identity of 'the oppressor', is oppressing them and preventing the full constitution of their own identity (Laclau, 1990: 21). Laclau calls this situation a relationship of 'antagonism', whereby 'the oppressed [increasingly] constitute their identity by denying the identity of the oppressor' (Laclau cited in Worsham and Olson, 1999: 24). For Laclau, a relation of oppression is 'relations of subordination which have transformed themselves into sites of antagonism' (Laclau and Mouffe, 1985: 153-4). Moreover, it is precisely in these moments of 'antagonism' that the 'undecidable nature' of the given set of social relationships become 'visible', because here the unequal and hierarchical power relationship that had previously appeared as normal and natural are now destabilised and rendered potentially open to change (Laclau, 1990: 35).

It is clear from this brief summation, firstly that Laclau shares a great deal with the neo-republican conception of the exercise of arbitrary power. At the same time however, it is evident that Laclau's understanding of the relationship between structure and agency is not just concerned with the arbitrary will of individual agents but also the arbitrary power of social relations, processes, norms and practices that place some individuals and groups in subservient positions and others in positions of control and influence. He also appears to have a far stronger emphasis on the circumstances by which oppressed groups become conscious of relationships of subordination and thereby draw those norms and practices into question. We will see in subsequent sections that these differences further play out in their respective conceptions of political struggle. First however, we can further accentuate these alternatives by returning to A Doll's House. Although Laclau does not himself offer a reading of the play, we can nonetheless consider the relationship between Nora and Torvold from a Laclauean perspective and contrast this with Pettit's reading.

Pettit's interpretation of $A$ Doll's House demonstrates his concern with the agentic relationships between two individuals. Pettit's emphasis is clearly on the ways in which Nora is subject to the idiosyncrasies of Torvald's will, attitudes and decisions. But the 'subject positions' of these two agents are also established within a wider system of subordination. Nora is a subject of nineteenth century Norwegian

\footnotetext{
8 See also Howarth et al, 2016.

${ }^{9}$ Kolodny (2014a; 2014b) questions Pettit's use of the term domination and suggest that the examples he provides such as the slave and the slave holder or patriarchal relations are instances of relations of subordination and more specifically relations of superiority and inferiority. He says they are relations of social inequality.

10 See Vrousalis (2013) for whom domination is not just asymmetrical power relations (power over) where one agent affects another but where the power-overing is done so in a way that is disrespectful (demeaning, degrading, humiliating). For Vrousalis, the relation between master/slave, serf/lord and husband/wife in the patriarchal family all involve disrespect (140). He theorises domination from a third person perspective looking at the relationship between two agents. For Laclau, domination is the perspective from the individual/group who becomes aware that she/he is subordinated and subjugated to unequal social relations such as hierarchy or patriarchy. Laclau's conception of subordination shares similarities with Niko Kolodny's (2014a; 2014b) concerns about subordination understood as inequality in social relations (relations of inferiority and superiority) that enables some people to have greater opportunity to influence decisions and outcomes.
} 
society which legitimates patriarchy. Her identity as a daughter, wife, and mother is constituted by a system which considers such subordination normal, natural and therefore legitimate; and she doesn't contest her identity or consider herself 'oppressed'. In the act of marriage, Nora is handed over as an object of property from her father to her husband, with whom a similar subordinate relationship is reproduced (Ibsen, 2104: 40). The normalising power of these structures mean that Nora and Torvald are each socialised into their respective subject positions, they internalise and identify with them. On a Laclauean reading (and following Althusser and Jacques Lacan), we might say that Nora (like all subjects) has an imaginary relation to her own lived conditions of existence. Nora doesn't consider her relationship with Torvald to be unjust, i.e. to be a relationship of 'domination' or 'oppression', or at least this is so up to the point when her imaginary relation with Torvald is shattered. This happens in a crucial 'dislocatory' moment in the play, that is, when Nora grasps that Torvald wouldn't risk his life, honour, or status to save her (Ibsen, 2014: 39). standing At this point, the forms of identity and identification that sustain Nora's subject positions are interrupted or dislodged, and she begins to question the legitimacy of her society and the background structures which treat her unfairly. It is clear also that the kinds of solutions that Pettit proposes to address relations of arbitrary power - i.e. legal protections and safeguards that limit the capacity for one individual to exercise arbitrary power over another - cannot address the modes of subordination built into these background structures. On the Laclauean reading, what is required instead is an understanding of how Nora could turn this initial moment of 'dislocation' into a set of political demands that might start to draw the existing institutions into question, and to further understand these requirements we turn now to Laclau's reworking of the ideas of emancipation and freedom. Again, a comparison with the neo-republican perspective is helpful in bringing out the distinctiveness of his approach.

\section{From Domination to Emancipation and Freedom}

Since the early modern struggles to abolish the transatlantic slave trade, the idea of 'emancipation' has been associated with the act of setting someone free from a relation of oppression or bondage. Emancipation is clearly an important category in Marxist theory, evident for example in Marx's analysis of the modern wage/labour relationship in terms of 'wage slavery', and manifest also in his famous distinction in On the Jewish Question between mere 'political emancipation' (in the form of bourgeois civil rights) and genuine 'human emancipation' (characterised by the abolition of private property, and hence of 'wage slavery') (Marx, 1994). The term 'emancipation' is also a central category in Laclau's post-Marxist theory, and this is evident in the collection of essays he published in 1996 with the title Emancipation(s). In this section, we see that the term derives from the Roman republican tradition, and I consider points of contrast between 'emancipation' and the related notions of 'liberation' and 'freedom'. I first recall the etymology of the term 'emancipation', before exploring the way this idea functions respectively in Pettit's and Laclau's theories. Surprising perhaps, given his explicit reference to the master and slave relationship, we see that 'emancipation' does not play any significant part in Pettit's neo-republican theory. There are in fact good reasons for this, and again these insights point towards key differences between Pettit's neorepublicanism and Laclau's post-Marxism. To further draw out these differences, I read their respective positions in light of Marx's political/human emancipation distinction; with Pettit's theory operating exclusively at the level of formal political rights and freedoms, whereas Laclau's approach retains important characteristics of what Marx called 'human emancipation', albeit also with important qualifications.

The term 'emancipation' comes from the Latin emancipatusis, which is a compound of two Latin words ex and mancipum, which signify 'away' and 'ownership' respectively; hence emancipatusis means to 'give away ownership'. In Roman law, 'emancipation' did not in fact refer to the liberation of slaves from their bondage, but to a legal mechanism for releasing someone (child/or wife) from the control of another (father/husband) and thus altering their status (Gardner, 1998: 10). The term was used to refer to 'freeing of a son from the legal authority of the male head of the family, thus making him responsible for himself in law' (Roberts, 2014: 583; Gardner, 1998: 10). Although sons could establish independence in this way, this 
did not apply to a slave because of his/her status in society was considered as a 'thing' and not a person. However, slaves could become 'liberated' from their bondage, but this was through the process of 'manumission' which took the form of 'ceremonies performed by the master, [and] legally recognised within a society' (Harrill, 1995: 4). Despite these subtle differences, following the modern struggle against chattel slavery: the terms emancipation and liberation have come to be seen as more or less equivalent, and they have been generalised to refer to any struggle to liberate someone from injustice and oppression, and often against the will of the 'oppressor' (Biesta, 2010: 41). In other words, since the time of the Enlightenment, emancipation has come to mean 'the liberation of slaves without the observance of any manumission procedures [and] regardless of the slaveholder's [or master's] interests' (Harrill, 1995: 4). In the 18th century, the term emancipation was 'used in relation to the emancipation of slaves, in the 19th century to the emancipation of women and workers' and in the $20^{\text {th }}$ century to the independence from colonial rule (Hewlett, 2007: 1; Biesta, 2010: 42). Marx's use of the term clearly follows in this same broad tradition (See Hewlett, 2007).

Given Pettit's invocation of the master/slave relationship to describe the circumstances of domination, we might expect him also to model a theory of politics on the idea of emancipation. However, in fact we find that, apart from few scattered references, emancipation plays no substantive or significant role in Pettit's neo-republicanism conception of freedom as non-domination. The reason for this is that the point of departure for Pettit's analysis is existing western democracies where the status of individuals has been formally equalized in law. Indeed, this context of formal equality under the law sets the basic parameters for Pettit's approach where his focus is on 'arbitrary relations' of power that manifest in the dynamics between individual agents. However, background structures of inequality and undue influence or what Niko Kolodny calls unequal social relations persist under conditions of formal equality and in democracies (Kolodny 2014a; 2014b). So, whilst Pettit states that 'freedom involves emancipation from any subordination, liberation from any such dependency' (Pettit, 1997: 5), his invocation of the master/slave metaphor functions only as an analogy. His is not a politics of setting someone free from an oppression, because all individuals are already considered equal citizens of the democratic republic. Instead, Pettit's concern is to counter the residual elements of arbitrary power that some agents wield over others, and this through legal redress as well as a politics of contestation. Nevertheless, as we will see in more detail in the final section, this is a politics that is played out essentially within the context of the existing institutions.

If we turn the categories that Marx introduced in On the Jewish Question, we could say that Pettit's approach operates exclusively at the level of what Marx calls 'political emancipation'. Marx used this term to describe the formal freedom of individuals, characteristic of modern liberal democracies, and which he associated with the liberation of the bourgeoisie from premodern aristocratic and feudal structures. On Marx's reading, modern democracies clearly allow (some) individuals a degree of freedom in the form of rights and protections from state interference, but this formal freedom is intrinsically linked to an atomistic vision of society (which is destructive of genuine human sociality), as well as to 'real' capitalist social relations that are anything but free, i.e. for the class of labourers who are forced to sell their labour power under impoverished and exploitative conditions (Marx, 1994). Marx was of course aware that the circumstances of modern wage labourers are different from ancient and modern forms of slavery, but the deeper point is that there is nonetheless elements of force, influence and exploitation inherent in capitalist wage/labour relations, despite the formal freedoms of employment contract, or, more generally, despite the supposedly 'contractual' basis of modern state and society (Marx, 1994). Marx is not entirely dismissive of modern formal political and civic freedoms, but the key point is that - even if the formal rights of citizens are extended to the labourers themselves (as of course they have been since the time of Marx's writing) - the 'bourgeoisie revolution' is nonetheless only one stage in the direction of a more fundamental movement towards genuine 'human emancipation' which Marx associated with a more fundamental set of changes in the underlying social order of capitalist society. And this can only be achieved through the 'selfemancipation' of the working class from the tutelage of the wage/labour relationship (Engels, 1990: 60). 
Laclau's theory breaks with some of the core assumptions at work in Marx's account of 'human emancipation'. Most significantly, Laclau rejects the claim that the 'exploitation' characteristic of the wage/labour relation represents the single most important fault line of oppression that underpins modern capitalist society (Laclau and Mouffe, 1985: 124-5). On Laclau's account, capitalist exploitation must be placed on an equal ontological status with other fault lines of domination, e.g. gender oppression, the oppression of diverse sexualities, of the environment etc. He also clearly rejects the teleological assumptions of Marx's theory of history, which presume a certain necessity in the forthcoming proletarian revolution and which portray the post-revolutionary communist society in terms of de-conflicted or pacified society; seen as synonymous with the realisation of 'man in his species being' and with a postpolitical 'administration of things' (Laclau and Mouffe, 1985; Laclau, 1990; Marx, 1994). These assumptions drop out of Laclau's post-Marxist and anti-essentialist approach. Nevertheless, despite these theoretical moves, it is evident also that Laclau retains what is arguably the core of Marx's political/human emancipation distinction, which is the idea that any genuine politics of emancipation must contest the underlying structural sources of subordination that persist in modern societies (unequal social relations) despite our formal equality as citizens, and that the moment of 'emancipation' allows for the possible emergence of a different kind of institutional ordering. Indeed, Laclau has been explicit in asserting that we need to retain and rework these core elements of conventional Marxist theory. In Laclau's terminology, this means a) that the struggle for emancipation has an essentially 'dichotomous' form, in the sense that any moment of emancipation is mutually exclusive, i.e. forms a decisive break with, the order that preceded it, and b) that emancipation has an intrinsic 'ground dimension' in the sense that it must take place at the foundations of the social fabric and not just at the level of political and legal institutions, so that all spheres of society are potentially transformed (Laclau, 1996: 2). It follows from these insights that Laclau's understanding of politics cannot be reduced to a defence of existing liberal democratic institutions, as suggested by some of his more conventional Marxist critics (Geras, 1988: 2, 54). Not only is Laclau's conception of emancipation incompatible with Berlin's vision of 'negative liberty', Laclau's positon is incommensurate with any more general defence of the status quo. Whilst rights and formal legal protections are important, their realisation does not exhaust the sources of oppression in society, and Laclau's politics reaches out for a more fundamental shift in the existing institutions, whereby people will come to socially relate to one other in egalitarian ways that are distinct from the existing capitalist society.

However, despite this clear line of emphasis in Laclau's work, we need also to further distinguish between his conception of 'emancipation' and 'freedom'. In Laclau's theory these terms are not synonymous. Moreover, I would suggest that there are in fact two core aspects to Laclau's idea of 'freedom', again neither of which are compatible with the idea of 'negative liberty' or reducible to the possession of formal political rights. This is freedom understood respectively as indeterminacy and as something like self-determination. We have already examined Laclau's conception of freedom as indeterminacy in the previous section, i.e. in his theory of structural 'dislocation'. Indeed, Laclau thinks of freedom as indeterminacy when he writes that it is because of 'dislocation', i.e. because of the failure of the structure to fully constitute the subject as an object, that there is freedom (Laclau, 1990: 44, 47). Indeed, this 'absence of determination', provides a crucial moment in the emergence of any political struggle, and so the 'greater the structural indetermination' in a given conjuncture of social forces, the 'greater the freedom' (Laclau, 1990: 35, 40). This conception of freedom as indeterminacy is distinct both from the struggle for emancipation (i.e. a struggle for liberation from 'oppression', which we have just outlined above), and from the idea of freedom as a creative and collective act of self-generation. This latter conception of freedom Laclau associates with the emergence of a new hegemonic/symbolic order, with the self-determination by a people or populous, which can (but not necessarily will) arise from a struggle for emancipation (Laclau, 1996: 1, 13). ${ }^{11}$ Implicit in these distinctions is the assumption that the struggle

\footnotetext{
${ }^{11}$ For Laclau, freedom involves self-determination where an 'act of decision' takes place in an undecidable terrain (1996b, 52, 54). This is different from Pettit's notion of political decision where a resolution is reached after rational consideration and deliberation. For Laclau, following Derrida, 'decision' or 'madness of the decision' cannot be rationalised and it provides the conditions for the emergence of the subject (1996b; 54, 55).
} 
for emancipation is a necessary but insufficient element in the actualisation of 'freedom'. In this regard, Laclau is, I think, close to the fundamentals of two other continental thinkers, Hannah Arendt and Michel Foucault. Despite otherwise significant difference in detail; each of these three thinkers differentiate between what Laclau calls 'emancipation' (which for Arendt and Foucault is 'liberation'), i.e. a struggle to be liberated from necessity or oppression, and the notion of (what all three thinkers call) practices of 'freedom', and which they associative with something like an initiatory or generative moment (See Arendt, 1965; Foucault, 1984: 284-245). Like Arendt and Foucault, Laclau also places a premium on political contestation, i.e. as the source of this generative moment, and in the final section we look more closely at the detail of Laclau's understanding of political struggle. ${ }^{12}$ Again, the details of Laclau's understanding of politics are brought out through a comparison with Pettit's neo-republicanism.

\section{Pettit and Laclau on politics as contestation}

Laclau and Pettit both associate politics with contestation, and they each see political struggle as a key mechanism for challenging domination. This emphasis on the value of political conflict is often associated with 'agonistic' theories of democracy, which have recently been reconstructed by Mark Wenman (Wenman, 2013). Wenman emphasises the link between contemporary agonistic theories and the work of Machiavelli, who stressed the productive force that contest plays within the republic as a way of repeatedly challenging hierarchy and inequality. Neither Laclau or Pettit are typically associated with agonistic theory, however I think we can read each of their contributions as falling broadly within this tradition. Furthermore, in keeping with the differences we have thus far established, we see in this final section that Pettit emphasises the importance of the permanent possibility of contesting claims to power and authority within the existing institutions, i.e. as a necessary condition for challenging arbitrary power (Pettit, 2007: 102). Whereas, for Laclau, the decisive element of political struggle is associated with the moment that the existing regime is unable to accommodate and contain a series of political demands, at which point he says we see the emergence of a genuinely populist movement, one that has the potential to alter the symbolic horizon of meaning and hence to establish a new institutional order. Again, these are significant differences, and the objective here is to compare them. I nonetheless conclude with the claim that they are each represent important dimensions of political struggle.

Thus far, we have seen that Pettit highlights the role of legal protections, which are designed to limit the capacity for arbitrary interference either by the state over its citizens or of one individual over another. However, unlike the predominant strands within contemporary liberal theory, Pettit does not think we can fully ensure the freedom of citizens through legal mechanisms or on the basis of procedural neutrality. Because of his emphasis on individual agency, Pettit is concerned with the element of discretion that resides in decision making (despite formal rules and procedures), and so he is focused on the need for institutions and forums that will enable citizens to challenge and contest government/public decisions (Pettit, 1997:187,277). He develops a rich account of a 'contestatory democracy' understood as a supplement to the main institutions of electoral democracy, and at the heart of which is the idea of the right of the people to call public decisions into question. Indeed, Pettit understands contestation in terms of an individual's or a minority community's capacity to review legislation and administrative and judicial decision making; that is when they can show that their 'avowable perceived interests' have been ignored (Pettit, 1999: 181: Pettit, 1997: 195). This might take the form of bringing a particular decision 'before a public commission or parliamentary inquiry on the grounds that it is improper in some way, challenging it before an administrative appeals tribunal, or complaining about it to an ombudsman' (Pettit, 1999: 181). This implies that the people have a certain 'editorial' role in democracy in addition to the 'authorial' role of

\footnotetext{
12 Several contributors - including Foucault, Jacques Ranciere, and various feminist writers - have stressed limitations in the idea of 'emancipation'. The struggle for emancipation can become a trap, because it inscribes the oppressed into a set of subject positions constructed by the dominant regime of power. The emancipatory logic also seems to imply that the oppressed person becomes free because of the act of emancipation, and this can 'install dependency into the heart of emancipation' (Biesta, 2010: $41,45)$. Laclau is mindful of these problems, and careful to insist that emancipation is a necessary but insufficient condition of freedom understood as self-determination.
} 
their collective will, and in particular, this allows for a check upon the excesses of the majoritarian principle, which, says Pettit, can often be the source of an 'ultimate form of arbitrariness' (Pettit, 1997: 8).

Pettit's emphasis on democracy as contestation has come under considerable criticism. For example, David Owen (2009) shows how Pettit's theory reduces contestation to a vehicle through which we negotiate conflicts of interests rather than a medium through which we work out our civic identities; John McCormick (2011) makes the case that Pettit's contestatory procedures are not at the fore of his conception of politics but operate only in a reactive manner where citizens react to governments and Richard Bellamy (2016) suggests that, in reality, all voices do not get an equal hearing and that the wealthy are most likely able to trigger the review of political decisions in this way. Consider for example, the recent case of Gina Miller who took the UK government to the Supreme Court over its handling of Article 50. These are important and insightful criticisms, and I broadly concur with the view that Pettit offers an overly narrow conception of political contest, which is of course in keeping with the main characteristics of his theory we have outlined in the previous sections. My sense is however, that the kind of politics that Pettit describes nonetheless remains an important element in the struggle against subordination, and I come back to this in the conclusion. First however, we need to compare his conception of politics with Laclau, and of relevance here is Pettit's insistence that 'popular movements' do not form the basis of his theory of democratic contestation (Pettit, 1997: 195). Indeed, Pettit is clear that his objective is to provide mechanisms whereby individual citizens can exercise greater control over public decision making (Pettit, 2012: 185). Moreover, this will often involve an element of 'depolitisation', so that cases can be heard by experts and away from the tumult of popular discussion (Pettit, 1997: 2012). The process of 'depolitisation' is deeply problematic for challenging subordination and arbitrary power and as Bellamy identifies it cannot escape power relations and therefore risks engendering domination (Bellamy, 2007: 146-174; 175). As we will now see, these points of emphasis are in marked contrast to Laclau.

Like Pettit, Laclau accentuates contestation in his account of 'radical democracy'. He says, 'there is democracy [only] as long as there is the possibility of unlimited questioning' (Laclau, 1990: 187). However, we might situate Laclau's conception of democratic contest precisely where Pettit leaves off. As we have already noted in the previous sections, Laclau thinks of politics in terms of competing hegemonic struggles. Genuine politics, on Laclau's account, is not something that is contained within the existing institutions, but also refers to those moments of dislocation when one symbolic social order is drawn into question and is possibly superseded by an alternative regime. In his late work, Laclau elaborated these ideas in the terms of a distinctive theory of 'populism' (Laclau, 2005). However, there is a clear consistency in the detail of Laclau's conception of democratic struggle running throughout his publications, from the time of Hegemony and Socialist Strategy onwards, and the key elements in his approach are as follows. On Laclau's account, every political context is defined by a set of 'demands' and these demands are directed towards the existing institutions. The existing regime will seek to respond to these discrete demands and to prevent them forming any kind of equivalence with one another. To the extent that the demands are fulfilled, they will be repeatedly absorbed in the existing institutions. Pettit's politics of democratic 'redress' seems to operate exclusively at this level. However, Laclau is interested in what happens precisely when the politics of redress fails, i.e. when the existing regime is unable to absorb the individual demands. At this point, according to Laclau, the individual demands start to see themselves in a relationship of 'antagonism' with the existing regime, which increasingly comes to be perceived as the 'oppressor'. Here the demands also change from being 'requests' that could potentially be absorbed within the current system, to 'claims' that require broader transformations in the existing order (Laclau, 2005). Now the diverse demands also come to see themselves in a common 'chain of equivalence', i.e. they recognise their correspondence with each other in their shared opposition to the exiting regime that oppresses them all. This creates a 'frontier effect' or dichotomous struggles of 'us versus them'; and from here on the demands are engaged in a more general struggle for 'emancipation'. Finally, to the extent that this struggle is successful, one of the demands begins to operate as a representative or a stand in for the series of demands, that is, it comes to 
embody a 'generalised demand' that might, in turn, form the basis of a new symbolic or hegemonic order. ${ }^{13}$

Once again, we see that there are important points of similarity but also crucial differences between the neo-republican and post-Marxist conceptions of politics as contestation. Where Pettit's focus is clearly on the importance of democratic contest within the context of the existing institutions, Laclau's conception of politics as the struggle for hegemony exhibits important continuities with Marx's idea of 'human emancipation'. Indeed, Laclau associates the function of the 'generalised demand' with the embodiment of a certain 'universality' or fullness, i.e. that transcends the particularity of the discrete individual demands, and in his late writings Laclau linked this moment of universality with 'populism' and with the construction of 'the people' (Laclau, 2005: 223). At the same time however, we must note also once again important qualifications in Laclau's post-Marxism, because on Laclau's reading the hegemonic embodiment of universality only ever takes the form of a temporary personification of an (essentially) absent fullness, and so this moment of plenitude could never be fully realised, for example in the form of a communist society at the 'end of history' (Laclau, 1996: 47-65). In fact, Laclau understands democratic politics precisely in terms of an open-ended (non-dialectical) struggle of different groups to temporally stand in for this impossible fullness.

\section{Conclusion}

The juxtaposition with Pettit's neo-republicanism has accentuated certain facets of Laclau's theory. We have seen how his is not a theory of contestation internal to the existing institutions. To the contrary, there are important elements of continuity between Laclau's work and aspects of classical Marxism. We have noted also several limitations in Pettit's approach. I nevertheless conclude with the thought that both neo-republicanism and post-Marxism provide important insights for the perennial struggle against subordination and arbitrary power.

The movement of democratic struggles over the past three centuries has overturned many forms of oppression in western societies. This has given rise to the formal equality of citizens, but these struggles have also altered, to some degree, the more structural conditions of oppression embedded in wider societal norms and practices. For example, the position of women in society has changed significantly because of several waves of feminist activism, and we no longer recognise many of the societal norms that formed the backdrop to Ibsen's A Doll's House. Having said that, it is also evident that western societies are still characterised by many hierarchical and oppressive social relations and forms of inequality, and the relationship between western and non-western states and societies is also characterised by entrenched and systemic structures of power. Because of these ongoing conditions, Pettit's focus on a politics of redress within the existing institutions is a step towards politics of 'non-domination', but neither should we entirely dismiss the kinds of politics that Pettit describes and focus exclusively, with Laclau, on moments of hegemonic transformation. As some critics of Laclau have pointed out, his theory 'has little to say' about the specific institutional arrangements that might facilitate radical democracy (Keenan, 1995: 82). And it is precisely at the level of institutionalised contestation, where Pettit makes a valuable contribution. Indeed, we don't have to choose decisively - at the level of theory - between these alternatives, and we should see them instead as both relevant strategies in an overall struggle against subordination. ${ }^{14}$ By way of closure, we can further illustrate the potential complementarity of these perspectives regarding the thought of John Locke. Indeed, Pettit likens his model of contestatory democracy to Locke's conception of popular sovereignty under a mixed constitution, which enables the citizens to contest the decisions of their representatives and to resist abuses of power (Pettit, 1999: 183; Lovett and Pettit, 2009: 25; Pettit, 2012: 213). This is an important tradition in modern political thought, one which links back also to Machiavelli's emphasis on the productive role of contest within the republic, and I think this vision of politics continues

\footnotetext{
13 This summary of Laclau's approach is reconstructed from several sources across his various publications. As we have noted, there is a remarkable consistency in the core elements of Laclau's conception of the struggle for hegemony, from 1985 onwards. ${ }^{14}$ From Glynos's and Howarth's (2007) social logics perspective, we could say that the differences between Laclau and Pettit are that Laclau's focus is on ontological conditions (the political) whilst Pettit's is ontic issues (politics).
} 
to be of great importance in the context of contemporary political struggles. There are times however, when the struggle with arbitrary power requires citizens to go further; to reclaim what Locke calls their 'natural power or liberty' from the existing institutions, so they might reconstitute the body politic in the form of a new institutional order. In Locke's thought this implies a natural right to resistance and revolution, and in Laclau this is the ever-present possibility of a decisive moment of transition to a new hegemony.

\section{Bibliography}

Allen, Amy (2015) 'Domination in Global Politics.' In Jonathon Trejo-Mathys et al (eds). In Domination and Global Political Justice. London and NY: Routledge.

Arendt, Hannah (1965) On Revolution. New York: The Viking Press.

Bellamy, Richard (2007) Political Constitutionalism. Cambridge: Cambridge University Press.

Bellamy, Richard (2016) 'Which Republicanism? Whose Freedom?' In Political Theory. 44, 5 (October): 669-

678.

Berlin, Isiah (1969) Four essays on liberty. New York: Oxford University Press.

Besson, Samantha and Marti, Jose-Luis Law. 2009. 'Introduction: Law and Republicanism - Mapping the Issues' in Samantha Besson and Jose-Luis Marti, eds., Legal Republicanism: National and International Perspectives. Oxford: Oxford University Press. 3-38.

Biesta, Gert (2010) 'A New Logic of Emancipation: The Methodology of Jacques Ranciere.' In Educational Theory, 60 (1): 39-59

Eagleton, Terry (1991) Ideology: An Introduction. London: Verso.

Engels, Frederick (1990) 'Socialism: Utopian and Scientific'. Karl Marx Frederick Engels Collected Works. Moscow: Progress Publishers.

Foucault, Michel (1994) Ethics. Essential Works of Foucault 1954-1984. Edited by Paul Rabinow. London: Penguin Books.

Friedman, Marilyn (2008) 'Pettit's civic republicanism and male domination.' In C. Laborde and John Maynor (eds), Republicanism and Political Theory Malden, MA: Blackwell. 246-268.

Gardner Jane (1998). Family and Familia in Roman Law and Life. Clarendon Press: Oxford

Geras, Norman (1988) 'Ex-Marxism Without Substance. Being a Reply to Laclau and Mouffe.' In New Left Review I (169), May-June.

Glynos, Jason \& Howarth, David (2007). Logics of Critical Explanation in Social and Political theory. London: Routledge.

Hardt, Michael and Negri Antonio (2009). Commonwealth. Cambridge, MA: Harvard University press. Harrill, James, (1995) The Manumission of Slavery in early Christianity. Tubingen: Mohr Siebeck.

Hewlett, Nick (2007) Balibar, Badiou, Ranciere: Rethinking Emancipation. London and NY: Continuum. Hirschmann, Nancy, (2009) Gender, Class and Freedom in Modern Political Theory. Princeton: Princeton University Press.

Howarth, David 2000. Discourse. Buckingham: Open University Press.

Howarth, David (2010) 'Power, discourse, and policy: articulating a hegemony approach to critical policy studies.' In Critical Policy Studies, 3,3-4: 309-335.

Howarth, David. Glynos, Jason. \& Griggs, Steve, (2016) 'Discourse, explanation and critique,' Critical Policy Studies, 10, 1: 99-104.

Ibsen, Henrik (2014) A Doll's House. New York: Global Classics.

Kolodny, Niko (2014a) 'Rule over None I: What Justifies Democracy?' Philosophy \&Public Affairs, 42, 195-

229.

Kolodny, Niko (2014b) 'Rule over None II: Social Equality and the Justification of Democracy.' In Philosophy \& Public Affairs, 42, 287-336

Keenan, Alan (1995) 'The Difficult Politics of Democracy.' In Political and legal Anthropological Review. 18, 1 (May) 75-82

Laborde, Cecile (2008) Critical Republicanism. Oxford: Oxford University Press. 
Laclau, Ernesto and Mouffe, Chantal (1985). Hegemony and Socialist Strategy. London: Verso.

Laclau, Ernesto (1990) New Reflections on the Revolutions of our Time. London: Verso.

Laclau, Ernesto (1996) Emancipation(s). London: Verso.

Laclau, Ernesto, (1996b) 'Deconstruction, Pragmatism Hegemony.' In Simon Critchley el al (ed) Deconstrcution and Pragmatism. London Routledge.

Laclau, Ernesto (2001) 'Can Immanence explain social struggles' Diacritics 31: 4, 3-24

Laclau, Ernesto (2005) On Populist Reason. London: Verso.

Lovett, Frank (2010) A General Theory of Domination and Justic. Oxford: Oxford University Press.

Lovett, Frank \& Pettit, Philip (2009). 'Neorepublicanism: A normative and institutional research program.' In Annual Review of Political Science 12: 11-29.

Marx, Karl (1994) 'On the Jewish Question' in Lawrence Simon (ed.) Marx: selected writings. Indianopolis: Hackett Publishing Company Inc. 1-26.

Markell, Patchen (2008) 'The Insufficiency of Domination' Political Theory, February 36, 1: 9-36.

McCormick, John (2003) 'Machiavelli Against Republicanism: On the Cambridge School's Guicciardinian Moments' Political Theory October 31, 5: 615-643;

McCormick, John (2011) Machiavellian Democracy. Cambridge: Cambridge University Press.

Mouffe, Chantal (1993) The Return of the political. London: Verso.

Mouffe, Chantal (2000). The Democratic Paradox. London Verso.

Mouffe, Chantal (2005) On the political. London: Routledge.Mouffe,

Owen, D. (2009) 'The Expressive Agon.' In Andrew Schaap (ed) Law and Agonistic Politics. Aldershot: Ashgate. 71-86.

Pettit, Philip (1997) Republicanism: A Theory of Freedom and Government. Oxford: Oxford University Press.

Pettit, Philip (2000) Democracy, Electoral and Contestatory. Nomos 42: 105-44.

Pettit, Philip (2003) 'Agency-Freedom and Option-Freedom.' In Journal of Theoretical Politics 15: 4, 387403.

Pettit, Philip (1999) 'Republican Liberty, Contestatory Democracy.' In Democracy's Value. Ed. C. HackerCordon and I. Shapiro. Cambridge, MA: Cambridge University Press. 163-190.

Pettit, Philip (2012) On the People's Terms. Oxford: Oxford University Press.

Pettit, Philip (2014) Just Freedom: A Moral Compass for a Complex World. New York: Norton: and Co.

Roberts. A. Edward (2014) A comprehensive etymological dictionary of the Spanish Language with families of words based on non-European roots Volume 1(a-g) USA: Xlibris LLC.

Sim, Stuart (2000) Post-Marxism: An Intellectual History. New York: Routledge.

Thompson, Michael (2013) 'Restructuring Republicanism Freedom.' In Philosophy and Social Criticism, 39, 12: 187-208, 208.

Vrousalis, Nicholas (2013) 'Exploitation, Vulnerability and Social Domination.' In Philosophy and Public Affairs. 41(2): 131-157.

Wenman, Mark (2003) 'Laclau and Mouffe: Splitting the Difference.' In Philosophy and Social Criticism 29 (5): 581-606.

Wenman, Mark (2013) Agonistic Democracy. Cambridge: Cambridge University Press.

Worsham, Lynn and Olson, Gary (1999). 'Hegemony and the future of democracy.' In JAC. 19(1): 1-34 